\title{
Innovation, Entrepreneurship and Clusters in Latin America Natural Resource - Implication and Future Challenges
}

\author{
Tomas Gabriel Bas (I), Ernesto Amoros (2), Martin Kunc (3)
}

\begin{abstract}
The natural resources play a very important role in the economy of the Latin America countries, but follow the classical models of resource exploitation and scale do not add much more value to the products or services like other knowledge-based industries (biotechnology or IT). The cluster approach assembled around the pattern of innovation and entrepreneurship characteristics can help to improve these kinds of industries. Nevertheless, the "Natural Resource Clusters" have a particular task and they are based primary in environmental characteristics. However, this type of clusters is very different from "Technology Clusters" with a high innovation and entrepreneurship structure that needs explicitly more intellectual capacities and non-specific environmental characteristics. The authors suggest that in Latin America, clusters, innovation and entrepreneurship based in the natural resources has a supplementary significance, but they need add much value based in the knowledge. This article discuss the challenge of Latin American economies and the implication to transform the natural resources based industries in others with more innovation and knowledge based assets and shows a framework based on Chile's particular experiences on salmon; wine and mining industries. Economics implications and future research are discussed.
\end{abstract}

Keywords:Technology, innovation, alignment of technology and innovation

(I) Universidad Adolfo lbañez.

World Bank and CONICYT Program Research 2005-2008

(2)Universidad del Desarrollo

World Bank and CONICYT Program Research 2005

(3)Universidad Adolfo lbañez

World Bank and CONICYT Program Research 2006-2008

Av. Diagonal Las Torres 2640, Peñalolen

Santiago, Chile 


\section{Introduction}

Chile, like most Latin American and developing countries, has extensive natural resource industries. The mining occupies the I st place of exportations, generates in national accounts $14.1 \%$ of GNP (Sofofa, 2004). Other extremely important natural resource activities, is the farm salmon, (4th place in Chilean exportations) with I.6\% of GNP. Usually, we can literally to speck of cluster in natural resources, because this industry is naturally concentred in a geographic region for environmental (climate, soil, water, etc.) circumstances. This characteristic is different of other types of clusters like a biotechnology or IT, because the technology cluster, need to born not just natural resources, but essentially capabilities like investments, infrastructure and intellectual capital with a very high specialization in knowledge (laboratories, universities, enterprises, policies, etc.) and this is sufficient for to begin without mattering the environmental place. These facts underreport their importance, as the statistics only relate to the core activities of resource exploitation, yet these industries link in many other kinds of economic activity. In a cluster framework, we would see much higher importance of the core resource industry. Industries like salmon and wine are divided in two categories, basic natural resources and manufacturing. In addition, resource industries show up much higher in export earnings, as mining alone, for example, represents $53.4 \%$ of foreign income earned and salmon as $4.6 \%$ (SalmonChile, 2004).

Not only these industries are important for Chile's economy in terms of jobs and exports, but also in addition, they offer potential for transformation to more knowledge-base variety of enterprise with more innovative forms and with the capability to continue adapting to new opportunities and developing higher value added products. Critical to this transformation obviously is the processes of innovation and entrepreneurship, functioning within a cluster structure (Bas, 2006).

This article is arranged by follow: First, we analyse the forms of innovation in Chile and Latin America for study the importance that acquire this figure in the generation of knowledge. The second point focus on entrepreneurship also in Chile and Latin America and their importance like a motor of the economy. Third, we looking the cluster structure in natural resource like a mode of join the concepts of innovation and entrepreneurship like a virtuous circle. The last point is concentrate on salmon industry in Chile, his evolution and structure, and the implications of innovation and entrepreneurship like an example of an eventual knowledge-based cluster.

\section{Conceptual Framework}

\section{Innovation in Chile and Latin America}

A process that takes an idea, or invention, links it to a market demand and turns it into a product, a technique or a service that is bought and sold can define innovation. Innovation also includes the improvement of an existing product or process and bringing it to market (Bonin and Desranleau, 1988). Innovation has critical dimensions relating to corporate management, evolution in trajectories over long periods and spatial location. The capacity to innovate of a country is determine by underlying capacities to produce and to apply knowledge.There are some indicators that measure innovation like: productivity; number of patents; publications; investment in R\&D; investment in venture capital; physical infrastructure, number of PhD, etc. (Bitran, 200 I, Niosi and Bas, 200 I, 2004; Bas, 2006; Benavente, 2004; Dutrénit and Katz, 2005). The innovation is important in alls economies because this generates knowledge, and this knowledge, to its turn generates more innovation, and we have a virtuous circle.

The term innovation appeared in a modern sense in 1934, when Schumpeter published The Theory of Economic Development and described the engine of economic development as innovation. Over the intervening seven decades, our understanding of the role and characteristics of innovation has greatly deepened and widened. It is recognized that the application of new knowledge and new technologies are key to innovation and its impact on the economic development (Nonaka and Takeuchi, 1995; Price, 1996). Growth theory emphasizes the role that the accumulation of knowledge has (Penrose, 1959; Nelson, 1993). A wide variety of research (Easterly and Levine, 2002; Niosi and Bas, 200 I; Bas and Niosi, 2007; Benavente, 2004) indicates that the different economic levels between countries are associated with the accumulation of productive factors such as technological and innovative activity. Innovation generates an impressive list of externalities (Fagerberg and Verspagen, 2003), which in turn spur development. It is also clear that innovation can be explicitly managed (Roberts, 2002). Therefore, innovation is important not only for developed countries, but for Latin America as well. Latin American countries suffer serious handicaps in creating innovations. The most important reasons are: Insufficient innovative and technological policies, low interaction between university, government and industry; high emigration rates of the best researchers; a very small scientific community; difficulties in publishing in international journals; low patenting; low industrial investment in R\&D; scientific work valued less than professional work in business. (Casas et al. 2005). 
In Latin America, many researches (Katz, 2000) have concentrated on sources of competitiveness and discovered that the tendency to patent continues to be insufficient. Lately there has been an improvement in the conditions to develop a system of sustainable innovation (Constantino, 2004), but there continues insufficient investment and output to reach levels of growth like that new industrialized countries like Taiwan or South Korea.A great deal of basic infrastructure investment is required in terms of labs, libraries, connectivity and education to close the gap with developed countries (Mayorga, 1997). In Latin America, innovations are primarily associated with adapting existing products, technologies, organizational or commercial strategies previously created in developed countries. Profits in these cases are generally lacking as products entry into mature markets. In consequence, new product creation is not associated with the development of new know-how (Perez, 200I).

Investment in R\&D in Chile passed from $0.3 \%$ of GNP in 1965 to $0.7 \%$ in 2007 , but that is very modest when the goal of this country was to arrive at I\% in ten years between 1965-1975. In addition, only I $3 \%$ of the cost in R\&D of Chile is spent by the private sector (Bitran, 200 I). Few university researchers work on local realities as they are continually chasing grants available only in developed countries, following priorities of international agencies and their better-endowed colleagues elsewhere. The table I shows the situation in 2001 .

Table I Patent in a Selected Group of Countries

\begin{tabular}{lll} 
Country & Patent/Million Habitants & $\begin{array}{l}\text { Investment in R\&D by \% } \\
\text { GDP }\end{array}$ \\
\hline USA & 230 & 2.5 \\
Japan & 184 & 3 \\
South Korea & 100 & 2.8 \\
Argentina & 1 & 0.4 \\
Brazil & 0.4 & 0.8 \\
Chile & 0.3 & 0.7
\end{tabular}

Source: Bitran, 200I

Chile will not be able to maintain its recent historical rate of growth (7\% GNP) if it does not reconstruct his productive policy based on the export of natural resources. The incorporation of knowledge and competitiveness to those same resources is imperative so the country can improve its innovation rates and impacts. (Mullin et al. 2004; Katz, 2000; Benavente, 2004). For that to occur, it is necessary to increase the investments in R\&D and to improve public policies for better protection of intellectual property and improve the investments on R\&D (Schumpeter, 1942; Solow, 1956; Romer, 1990; Freeman, 1987). One good example for this situation is the competitive analysis made by the World Economic Forum, WEF.All years, they develop a Global Competitiveness Report that includes a Growth Competitiveness Index (GCl). For year 2005, the table 2 shows the top ten economies in addition the better-ranked Latin-American countries for a 122 analysed economies. Chile is the best country ranked in a 23 position, but it is not sufficient for that continue to growth their economy in the future. The second Latin American country behind Chile is Uruguay in 54th position.

Another good example and important contribution for de WEF is the Global Information Technology Report that determines national information and communication technologies strengths and weaknesses, and evaluate progress in the participants' countries. Table 3 shows the top ten ranked economies in addition the ten best Latin-American countries for a 102 analysed economies. Chile, one again is the better Latin American country in 35th position, followed this time by Brazil in 46th position.

If we correlate these two indexes, we can observe a high correlation value (see figure I). In words of the Professor Dr. Klaus Schwab Executive Chairman, World Economic Forum 2005: -"But, as economists are prone to point out, what matters most is what happens 'at the margin,' and at the margin technologies today-particularly information and communications technologies (ICT) —are increasingly playing the central catalytic role in pushing the development process forward".

From this quick examination, we can spot several areas interesting for analysis:Why is the propensity to develop R\&D and technology so low in Latin America? Even though Chile is ranked on the top level in Latin-American economies, one important question is: How to increase investments in R\&D that increases the innovation capacity of the country so it adds greater value to the exports of natural resources? How public policies can create the necessary foundations to advance 


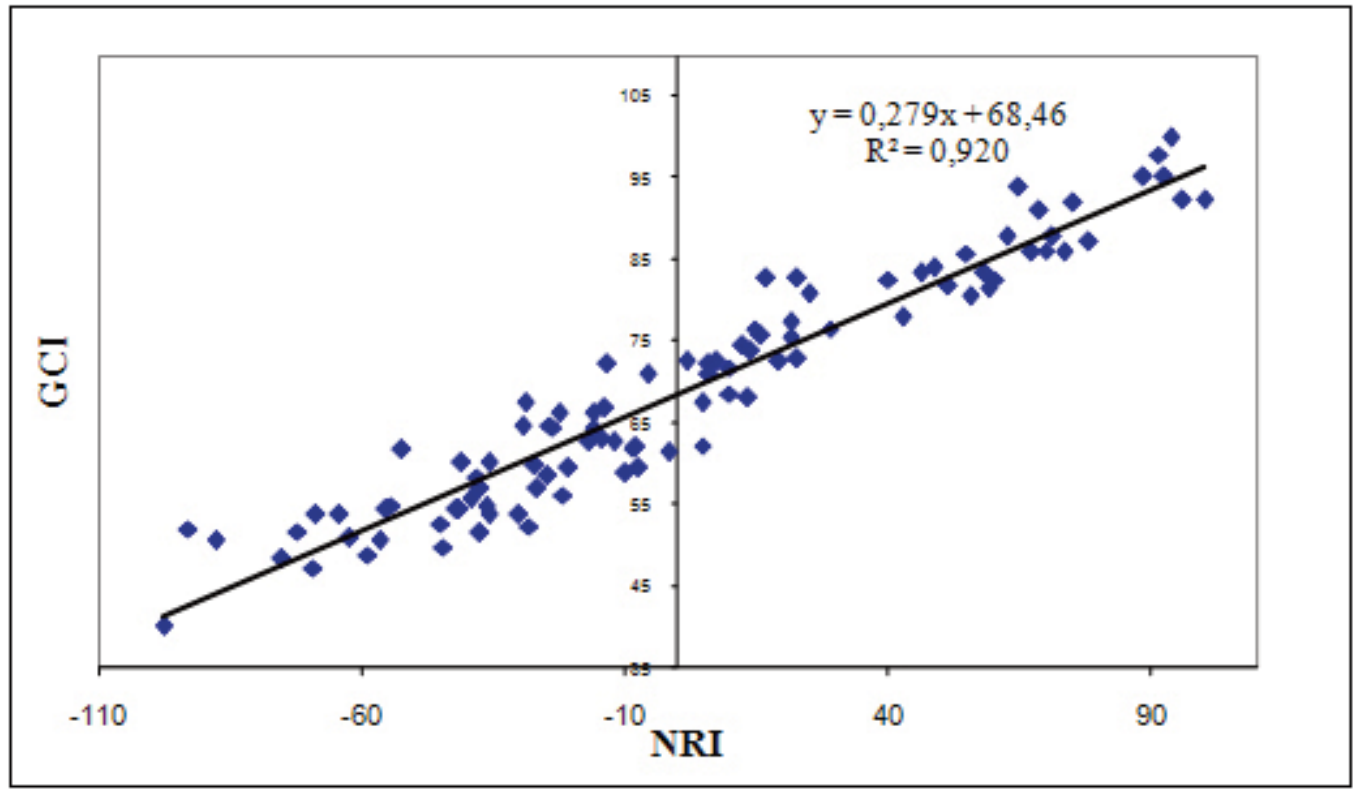

Figure I: Correlation between GCl and NRI, 2005.

Table 2: Sample of Growth Competitiveness Index Rankings, 2005

\begin{tabular}{lll} 
Country & Rank & GCl \\
\hline Finland & 1 & 5.94 \\
United States & 2 & 5.81 \\
Sweden & 3 & 5.65 \\
Denmark & 4 & 5.65 \\
Taiwan & 5 & 5,58 \\
Singapore & 6 & 5.48 \\
lceland & 7 & 5.48 \\
Switzerland & 8 & 5.46 \\
Norway & 9 & 5.4 \\
Australia & 10 & 5.21 \\
Chile & $\mathbf{2 3}$ & $\mathbf{4 . 9 1}$ \\
Uruguay & 54 & 3.93 \\
Mexico & 55 & 3.92 \\
Salvador & 56 & 3.86 \\
Colombia & 57 & 3.84 \\
Trinidad and Tobago & 60 & 3.81 \\
Costa Rica & 64 & 3.72 \\
Brazil & 65 & 3.69 \\
Argentina & 72 & 3.56 \\
Panama & 73 & 3,55
\end{tabular}

Source: Word Economic Forum, 2005. 
Table 3: Sample of the Networked Readiness Index Rankings (NRI), 2005

$\begin{array}{lll}\text { Country } & \text { Rank } & \text { NRI } \\ \text { Singapore } & \text { I } & 1.73 \\ \text { Iceland } & 2 & 1.66 \\ \text { Finland } & 3 & 1.62 \\ \text { Denmark } & 4 & 1.60 \\ \text { United States } & 5 & 1.58 \\ \text { Sweden } & 6 & 1.53 \\ \text { Hong Kong } & 7 & 1,39 \\ \text { Japan } & 8 & 1,35 \\ \text { Switzerland } & 9 & 1.30 \\ \text { Canada } & 10 & 1.27 \\ \text { Chile } & 35 & 0.29 \\ \text { Brazil } & 46 & 0.08 \\ \text { Jamaica } & 49 & -0.03 \\ \text { Trinidad and Tobago } & 59 & -0.28 \\ \text { Mexico } & 60 & -0.28 \\ \text { Costa Rica } & 61 & -0.29 \\ \text { Uruguay } & 64 & -0.39 \\ \text { Colombia } & 66 & -0.42 \\ \text { Panama } & 69 & -0.47 \\ \text { El Salvador } & 70 & -0.49\end{array}$

Source: Word Economic Forum, 2005.

knowledge and R\&D, as well as better distribute them? In doing this, we will need to compare Chile with appropriate industrialized countries (e.g. Australia, Canada) and with countries that are recently industrialized (Taiwan, South Korea). Evidently in Latin America there are some significant gaps related in which sectors is innovation occurring and how much money is putting on high growth initiatives and how could be possible to integrate all the actors on the industrial and services sectors. For understand these questions, we need to identify the value of entrepreneurship, because is hand in hand with innovation and a motor for economy growth and clusters setup.

\section{Entrepreneurship in Chile and Latin-America}

Entrepreneurship is the process of creating a new business. It refers both to the creation of a start up business by a small founding team with few initial resources, other than the concept, as well as the creation of a new branch of an existing business which benefits from knowledge and funding from the parent business, but operates and evolves independently (Shumpeter, 1911; Block and MacMillan, 1993).

As a field of research, entrepreneurship is a relative young and rapidly expanding field of knowledge. Not surprisingly, the word entrepreneurship has different meanings to different people, so is difficult to define precisely. Researchers stress that entre- preneurship is not only the act of creating the venture, but defines a set of personality characteristics, team functioning, management processes and business collaborations. The process of entrepreneurship in most general terms creates value for owners, participants and stakeholders, expressed within the paradigm of business management (Stevenson et al., 1999; Timmons and Spinelli, 2003). Entrepreneurship occurs not only in individuals, but also in firms, governments and non-governmental organizations and goes hand in hand with innovation (Drucker, 1985).

Entrepreneurship is a key motor for economic growth and new job generation (Birch, 1987). The Global Entrepreneurship Monitor Study, GEM, shows that a large number of people are engaged in entrepreneurial endeavours around the globe. Based on a sample of 35 countries representing a total labour force of 566 million, GEM research estimates that 73 million adults are either starting a new business or managing a young business of which they are also an owner (Acs et al, 2005; Minniti et al, 2006).

Entrepreneurship is vital for social and economic development in Latin America. Tiffin's (2004) study on this topic, with contributions from 13 authors shows rapidly increasing interest and involvement in nearly all countries of the region. Even though the research efforts on many aspects of entrepre- 
neurship in the region, there are very differing views about levels of entrepreneurship in Latin America. While the GEM studies consistently place Latin American countries among the most entrepreneurial in the world, others, operating outside the GEM methodology, show it considerably low, compared with other emerging economies like South-eastern Asia countries (Casas, Etzkowitz and Carvalho de Mello, 2005)

Chile has experienced a remarkable transformation in the last 20 years, both in terms of economic growth and institutional development. Export of natural resources or commodities (basically copper, wood, fruit and fish) and some low value-added processing led the economic expansion until the mid-1990s, but in the last few years the economic growth has showed variations and lower degrees of growth (Echecopar, 2004). For this reason, there is an emerging interest in opinion leaders from public administration, business and general society on how to develop more value-added industries. We think that entrepreneurship and innovation are keys to overcoming this recent lack of dynamism in the economy. There have been some recent studies of entrepreneurship in Chile, although within a more traditional economic framework and focusing on SMEs and their relation to new firm creation (Crespi, 2003). Other studies describe some factors on the start-up process and associated entrepreneurship programs (Echecopar, 2004, Tiffin, 2004). The last GEM study in Chile shows that the country has an important involvement in the entrepreneurship process, with nearly $60 \%$ of the study sample trying to develop an opportunity for a new business (Amorós et al., 2006) nevertheless, these results are distant from other indicators on develop and highincome countries, like Denmark, New Zealand or Norway; counties that exhibit most favourable ratios of opportunity based business, generally related with high value added industries (figure 2).

While in the last years there have been important efforts to understand entrepreneurship in Chile, they have not really shown any clear relationship between the creation of new business, innovation and networked clusters, nor any existence of virtuous mechanisms that will continue to improve the performance of critical economic sectors of the country.

Therefore, we intend to begin researching critical success factors in the creation of new business ventures, both start-ups and corporate entrepreneurship, entrepreneurship that is base on a high technology and knowledge innovations and promise to be platforms for creation of new industrial sectors in Chile. The country needs to transform the typical self-employment or new business venturing in primary extraction clusters from isolated experiences involved with local markets, to a strong,

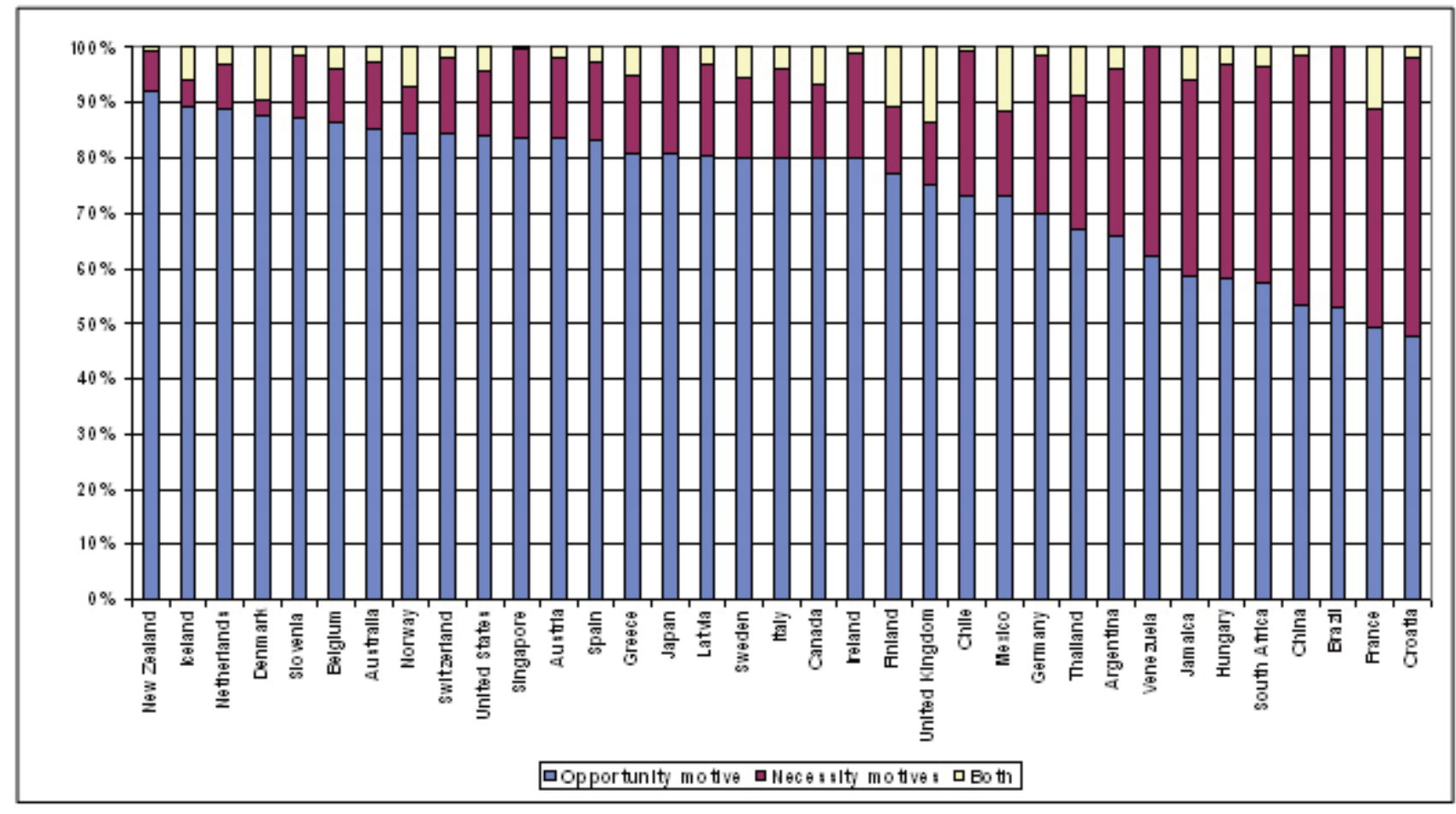

Figure 2: Opportunity to Necessity-base Early-Stage Entrepreneurship. GEM Study 2005

Source: GEM Global Report, 2005. 
networked innovations firms competing globally. For this commitment, is important to develop a more compressible theoretical model to understand this phenomenon on Latina America context. Second, we will do a networked map of new venture generation capability of selected industries; an understanding of how characteristics of technology and innovation influence the creation of new firms; and how entrepreneurial firms can improve their performance working on collaborative multi-firm network basically those young entrepreneurial small firms can engage in continuous innovation processes (Miles and Snow, 2005).

\section{Natural Resource Clusters around Innovation and En- trepreneurship}

We are interested in natural resources clusters as a mechanism for organizing and enhancing innovation and entrepreneurship. Clusters are generally seen as organizational structures that enhance industrial productivity and innovation. They concentrating a significant number of firms and related organizations that complement each other, stimulate competition and provide shared information, it is generally agree, they generate efficiencies that help firms compete in local and international markets (Porter, 2000). In the last few decades, the concept of industrial districts or production clusters has been extend to innovation clusters, where the group of firms has an enhanced capability to produce a continuous stream of new products and services. (Lundvall, 1992; Rosenberg and Birdzell, 1996).

However, there is substantially less material relating to clusters and entrepreneurship.Audretsch (1995), Feldmann (200 I), Rosenberg (2002), are some of the main contributors. Ireland, Hitt and Sirmon (2003), Goreman and McCarthy (2003), have proposed some concepts about business development that might be extended to cluster analysis, helping to join these rather separate concepts of entrepreneurship and innovation into a more common framework.

The difficulty with the cluster concept is to define which organizations are involved, based on what they share, how they influence each other and how they give a group of disparate actors some interactive, systemic characteristics. Models of clusters abound, to handle this complexity, with the most influential one promoted by Porter (1990), although it has been shown that his concepts do not hold fully in some industries and locations that are quite different than those in large urban centres typical of the USA (Niosi, 2005). Landry cuts this Gordian Knot by measuring interactions among players to determine by the strength and type of their ties to determine who is more in than out of the cluster and what role do they play (Keroack, Ouimet and Landry, 2003; Landry and Amara, 2004).

In defining, what clusters are and how they work, it is clear that they are characterized by relationships among organizations and people; tacit, associative, trust components are more meaningful than physical or infrastructure components (GomesCasseres, 1996; Burt, 2005). It is also important to get an idea of a cluster's spatial organization. While the literature focuses on local clusters (Hall, 1999) and national systems of innovation, it is also known that they are increasingly having global characteristics (Gibson and Stiles, 2000). In addition, most importantly, clusters are seen as structures that can evolve both to adapt to changing competitive circumstances and to more complex, higher-value added forms, if they have the right kind of knowledge and learning components and certain creativity characteristics (Florida, 2002).

Not surprisingly, industrialized countries researchers on developed economies have carried out nearly all the literature on clusters. Much of it refers to high tech industry (Niosi, 2005). How well it applies to Latin America and Chile is not clear, although we tend to think that the overall dynamics are universal. The subset of cluster literature that is focused on development in peripheral regions within developed countries (Cooke, 2002) seems applicable to this particular topic within the Latin American context.

Tiffin and Bortagaray (2002) presented one of the first comparative analyses of innovation clusters in Latin America. Since then, there have appeared at least two major comparative regional studies (Giuliani, Pietrobelli and Rabellotti 2004) and a small but important group of sectorial reports, most of them focused on production clusters in specific industries (see the above for a review).

In Chile, cluster studies have focused on wine and salmon. For wine, see: Giuliani and Bell (2004),Visser (2004), Hojman, (2005), Kunc (2007). Unfortunately, studies in global mining cluster are more recently and therefore too little, e.g. (Bas and Kunc, forthcoming). In Chile, the public activity in mining to create a cluster has begun, but the researches are very poor. In this case, the pioneer is the Antofagasta mining cluster.The word cluster is now widely used in the mining industry. Two studies on mining clusters have recently appeared on copper in Peru (Torres-Zorrilla, 2000) and bauxite in Brazil (Batista, 200I).

\section{Development of Knowledge-Based Industry within Na- tural Resource Clusters}

While there is a substantial literature on cluster learning and evolution (i.e. their capacity to create knowledge-based industry), the literature on these processes within clusters based on the extraction and processing of natural resources is much smaller. This is the critical issue for most developing countries, and certainly for Chile. 
Natural resource industries, although they are promoted by mainstream development thinking, have a bad reputation among certain specialists in the field. Sachs and Warner (200I) lay out this alternative viewpoint on the "curse of resource wealth". Katz (200I) claims that in the past decade, Latin America has deepened its specialization in resource extraction industries and weakened its position in more engineering-intensive industries.

However, the fact that these clusters are based on natural resources is not the only explanation of their limited ability to evolve. We do know that some individual firms have made long term and spectacular transformations from natural resource exploitation to diverse high tech products and services, like Mitsubishi (originally a lead-zinc mine), Otokumpu Oy (originally a copper mine) and Nokia (originally a forest products firm).They are exceptions. Most resource firms stay resource focused, like BHP (mining), although they may diversify downstream and upstream like Alcan, and become more technology focused. Most natural resource production industries follow boom and bust cycles as efficient, low cost, high volume producers.

In Chile, there is little awareness and involvement of industry in this kind of transformation; emphasis is still on increasing volume of raw material production and moving, in some cases, to higher value added products. On the public side, while there is increasing involvement in technological innovation and technology transfer, there is little awareness of these processes being accelerated within clusters. Chile follows classical models of resource exploitation, scale, efficiency, quality, but not innovation or upgrading. This seems to be a common pattern for most developing and developed countries with a colonial heritage, as the Science Council of Canada pointed out in its classic statement in 197I on Innovation in a Cold Climate.
Kunc (2006) presented a series of hypotheses related to the process of knowledge management that firms in the natural resource based sectors have applied to overcome their difficulties in the development of knowledge and its implications in innovation and performance of the firms. Basically, firms that have climbed up the ladder of innovation have developed absorptive capacities, participated in vertical and horizontal networks and established alliances or benefited from the interaction with foreign firms to acquire knowledge, achieved economies of scale in knowledge creation processes through public and private partnerships, and applied this knowledge in processes of vertical integration.

\section{Example: Salmon;Wine and Mining Industries}

\section{Farm Salmon Industry Evolution}

Enhance of fishing product consumption has tripled the last 45 years. This reason has harnessed the height of the aquiculture as tool of support to the strong demand of this type of proteins. The salmon-culture has maintained growth average of $26 \%$ between 198I and 200I. In 1997, the industrial farm salmon surpassed the captures of wild salmon for the first time, getting to represent a $55 \%$ of the worldwide production. In 200 I, this number it reached $64 \%$ of the total consumption on the world. The figure 3 shows this evolution.

\section{Farm Salmon Exportation in Chile}

Actually Chile is the second bigger salmon exporter of the planet (Norway is the first). These have a considerable impact in the economy of this country. Table 5 shows the evolution of growth rate of the exports in sales (Millions US\$) and the percent of the total country exports that is constitute by salmonids,

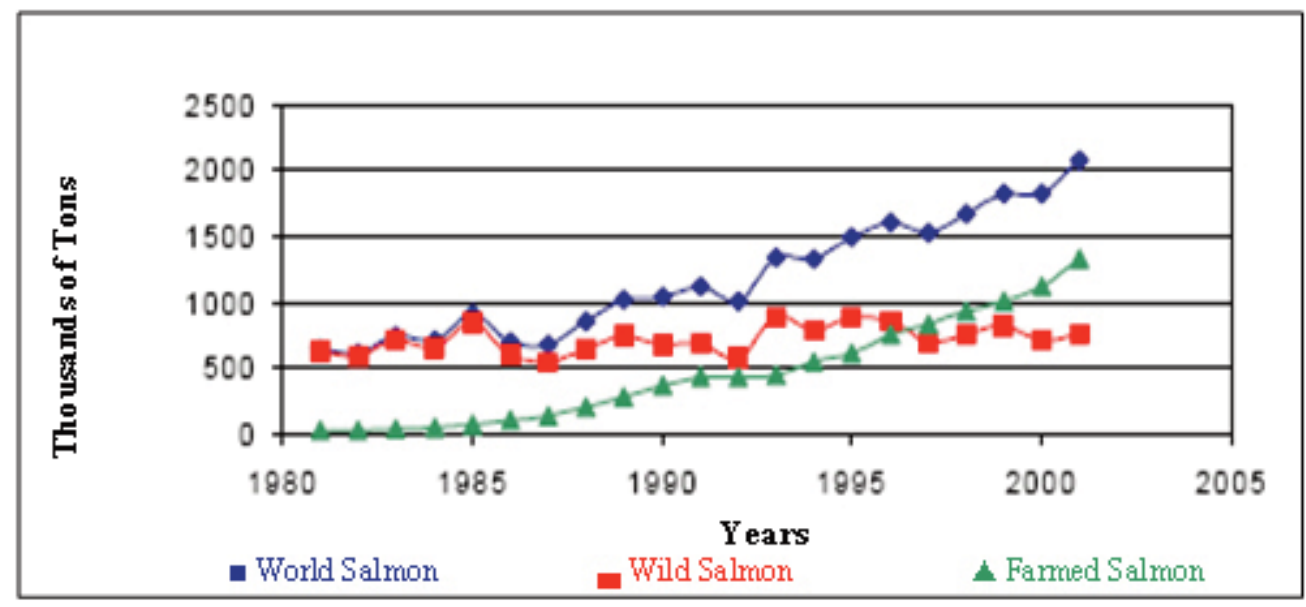

Figure 3: Total World Production, Coptures and Farmed Salmon

Source: SalmonChile 
from I99I to 2004. With exception of 200I (growth rate was $0.9 \%$, but with high fees near I 000 million US\$) the salmonids exports have a constant growth. In 2004 the salmon exports achieve 1439 million US $\$$ according to SalmonChile an industrial association which actually join the 47 best companies of the sector.

The salmon industry has generates 30000 direct jobs and other I5 000 indirect employs. According also to SalmonChile, in four years more, the industry will be generating 16000 additional positions, as well as new investments of the order of I460 million US\$. Inside this context, Chile and Norway has jointly participated in 2005 with $70 \%$ of the worldwide production of salmon. Chile with the $35.2 \%$ and Norway with the $36.8 \%$ of the total salmon farmed. The FAO assume that in 2030 the aquiculture will be providing the quasi totality of the fish consumed in the world.

\section{Salmon cluster in Chile}

Today there are more than 200 companies in-volved on the salmon industry, from which a $70 \%$ are located in Tenth Region (south of country). These companies correspond to activities such as the manufacturing of aquiculture and breeding cages, salmon food companies, manufacturing of nets, floating houses and warehouses, laboratories, vaccines and drugs, air and land transportation companies, underwater services, quality control, training centers, research and educational establishments, financial entities, insurance companies, specialized legal consulting and advisory services.

SalmonChile's forecasts show by 2010 , the industry will have made investments in the amount of US\$ I,460 million, most of which will be allocated to develop the sector in the I I th Region, anticipating the creation of 19,000 new jobs in the area.

Regarding salmon-culture sector, some applied research and consulting studies have been made. Montero (2004), Carbajal (2005), all use the con-cept of clusters in their work. They show there has been a great deal of innovation and entrepreneurship. It seems that much of it has been somewhat informal and largely vendor driven, where most of the vendors are from outside the country. This implies a low tech, follower strategy up to now, but still very significant as an initial development. There are a few major exceptions, where knowledge-intensive innovation and entrepreneurship have occurred (Echecopar and Tiffin, 2002), which lead us to suspect there might be more to be uncovered and more to be encouraged. The industry is well organized for production purposes, and CORFO, the government agency most directly and deeply involved in this topic, is starting to promote more formal aspects of clusterization. There is a new academic research project on environmental standards in the Chilean salmon cluster being made by lizuka and a new Chilean project is beginning under the direction of Vignolo. But, there is a real knowledge based cluster on the Chile's salmon industry? How many value added products and services are generated by the industry? There is a real focus of innovation and entrepreneurship processes with high international standards? For example, the evolution of the value-added export products (see figure 4), show that many of them can be consider only a manufacturing added process.

\section{Wine Industry in Chile}

The Chilean wine industry has achieved great success in terms

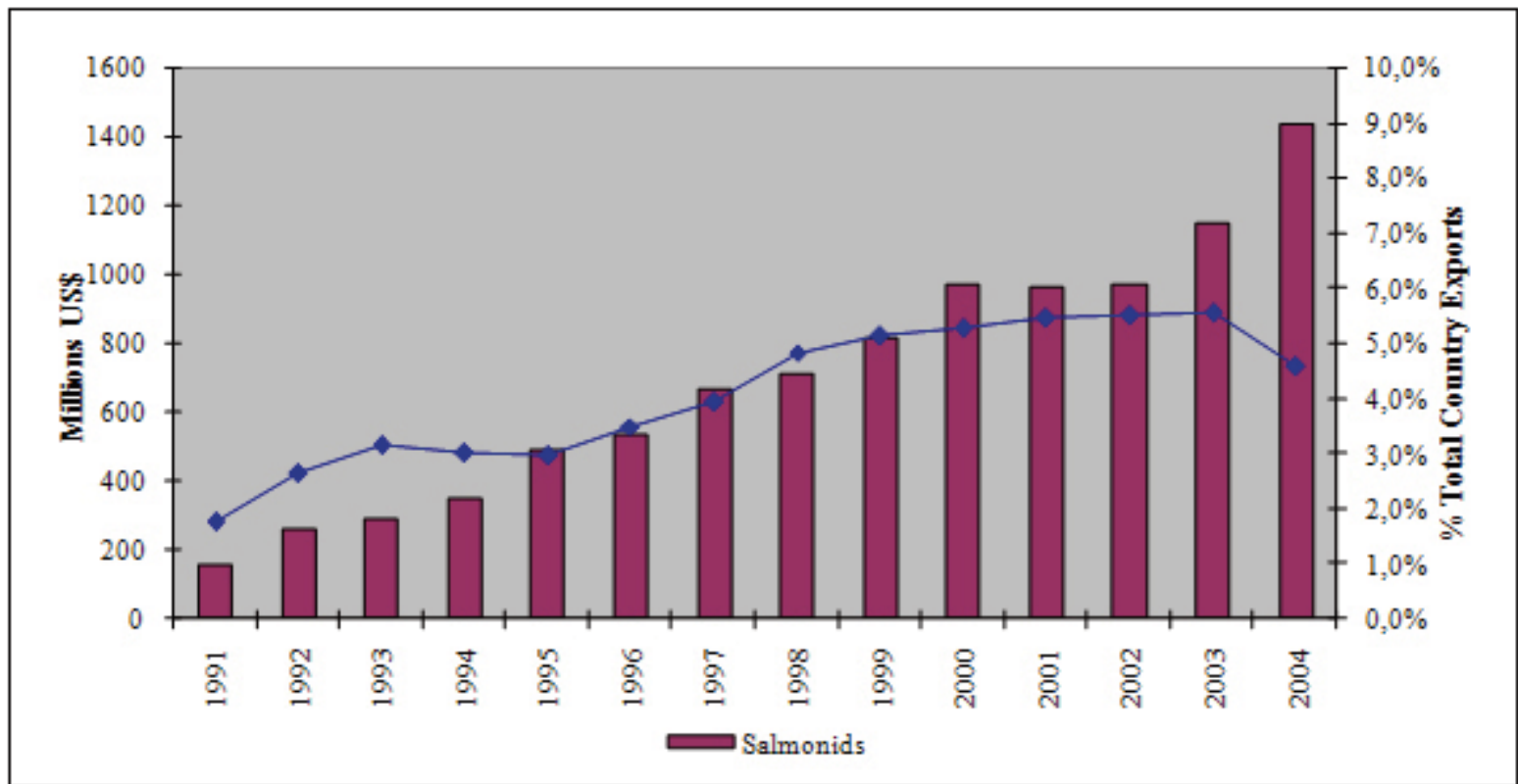

Figure 4: Salmon Exportations from Chile 1990-2004

Source: SalmonChile 
of exports but this extraordinary performance of the industry is not guaranteed. Kunc (2007) published the results of a survey to Chilean small and medium wineries about their actual managerial practices, which have contributed to the past success of the cluster. The findings indicate that Chilean wineries are following the right recipe for success in the wine industry but they may not be prepared to meet future challenges. To survive wineries' managers will need to pay more attention to distribution, marketing, consumer behaviour and cost management while maintaining its actual efforts in production and viticulture technology. The results also show that there are clustering processes aiming to exchange know-ledge in certain aspects of the wine value chain like viticulture (Kunc, 2006) or activities that are shared between many wineries like wine tourism (Kunc, 2008). At the level of National System of Innovation, two consortia have been established in recent years but the results from patenting are still very low (Kunc and Bas, 2007)

\section{Mining Industry System of Innovation}

Bas and Kunc (forthcoming) reviewed the national system of innovations in which the mining industry in Chile is based. They found that the importance of an international dimension of the Chilean mining industry given the globalised characteristics of the mining industry is not matched by the importance of its system of innovation. While Chile contributes with $36 \%$ of total copper production in the world, the investments in R\&D are very low compared with the revenues of the industry. Therefore, there are almost no patents originated in Chile registered in the USPTO data base. The results suggest that Chile is still depending on comparative advantages (huge volumes of copper mining resources with a low cost of exploitation) but progress is being done in innovating activities like Innova Minera.

\section{Conclusion and Future Research}

The literature related to the natural resources based on the knowledge is incipient and on devel-op. We not only want to point out this lack, but also we aspire to create conscience in the impor-tance of the construction of a network that allows to give value to a natural resource that would have sustainable and to be based more on the knowledge. It's important to re-

\section{Summary of Cases Reviewed by Bas and Kunc's Three-years Research Program}

\begin{tabular}{|c|l|l|l|}
\cline { 2 - 4 } \multicolumn{1}{c|}{ Salmon } & \multicolumn{1}{c|}{ Wine } & \multicolumn{1}{c|}{ Mining } \\
\hline \multirow{5}{*}{ Industry } & $\begin{array}{l}\text { Chile is the second big- } \\
\text { ger salmon exporter of } \\
\text { the planet. The salmon } \\
\text { industry has generates } \\
30000 \text { direct jobs and } \\
\text { other } 15000 \text { indirect } \\
\text { employs with } 200 \text { firms. } \\
\text { Mainly in south Chile }\end{array}$ & $\begin{array}{l}\text { The Chilean wine industry } \\
\text { has achieved great success } \\
\text { in terms of exports. Now } \\
\text { is the fifth largest exporter } \\
\text { in the world with almost } \\
\text { US\$ I billion. Seven dy- } \\
\text { namic wine regions located } \\
\text { in central Chile. }\end{array}$ & $\begin{array}{l}\text { Chile contributes with } \\
36 \% \text { of total copper } \\
\text { production in the } \\
\text { world. Huge exports } \\
\text { US\$36 billions } \\
\text { (2007). Mining activi- } \\
\text { ties concentrated in } \\
\text { the North of Chile. }\end{array}$ \\
\hline Topics & $\begin{array}{l}\text { There has been a great } \\
\text { deal of innovation and } \\
\text { entrepreneurship. It } \\
\text { seems that much of it } \\
\text { has been somewhat } \\
\text { informal and largely } \\
\text { vendor driven, where } \\
\text { most of the vendors are } \\
\text { from outside the coun- } \\
\text { try. This implies a low } \\
\text { tech, follower strategy } \\
\text { up to now, but still very } \\
\text { significant as an initial } \\
\text { development }\end{array}$ & $\begin{array}{l}\text { Chilean wineries are fol- } \\
\text { lowing the right recipe for } \\
\text { success in the wine indus- } \\
\text { try. There are clustering } \\
\text { processes aiming to ex- } \\
\text { change knowledge in cer- } \\
\text { tain aspects of the wine } \\
\text { value chain like viticulture } \\
\text { through consortia. }\end{array}$ & $\begin{array}{l}\text { R\&D are very low } \\
\text { compared with the } \\
\text { revenues of the indus- } \\
\text { try. There are almost } \\
\text { no patents originated } \\
\text { in Chile registered in } \\
\text { the USPTO database } \\
\text { but innovative activity } \\
\text { is perceived like Inno- } \\
\text { va Minera. }\end{array}$ \\
\hline
\end{tabular}


mark that the mining and the salmon contribute with the $15.7 \%$ of the total GNP in Chile, which shows the importance that these two industries based on natural resources have for this economy, to improve innovative and technological policies, incorporating greater competitiveness and knowledge to the natural resources. This element adds value to these resources, allowing the crea-tion of more efficient companies and therefore allowing the good performance of formed thus cluster.This indicate, the four issues (natural resources, innovation, entrepreneurship and cluster) jointly to the factors such as better public policies and more investment in education and R\&D they are friendly and therefore the true motor of the economies based on the knowledge, which we desire that they are the economies of Latin America in the next generation.

The figure 5 shows a proposal of research model found in na- tural resources based industries to study the different process (innovation, entrepre-neurship and cluster) that they lead to add more value at the natural resources based economy in Latin America.

The most important topics to analyze in the future research concern the strategies that allow increasing the knowledge in the industries based on the natural resources. Our example of the salmon industry illustrate the necessity of these kind of industries to increase the innovation degree and entrepreneurship processes to making more and better companies. The approach to construction a more stable growth in Chile and Latin America, is given by the generation of know-ledge that would have to be transformed in an innovation process with a value chain (innovation, entrepreneurship and clusters) and a better generation of sustainable natural resources in the time.

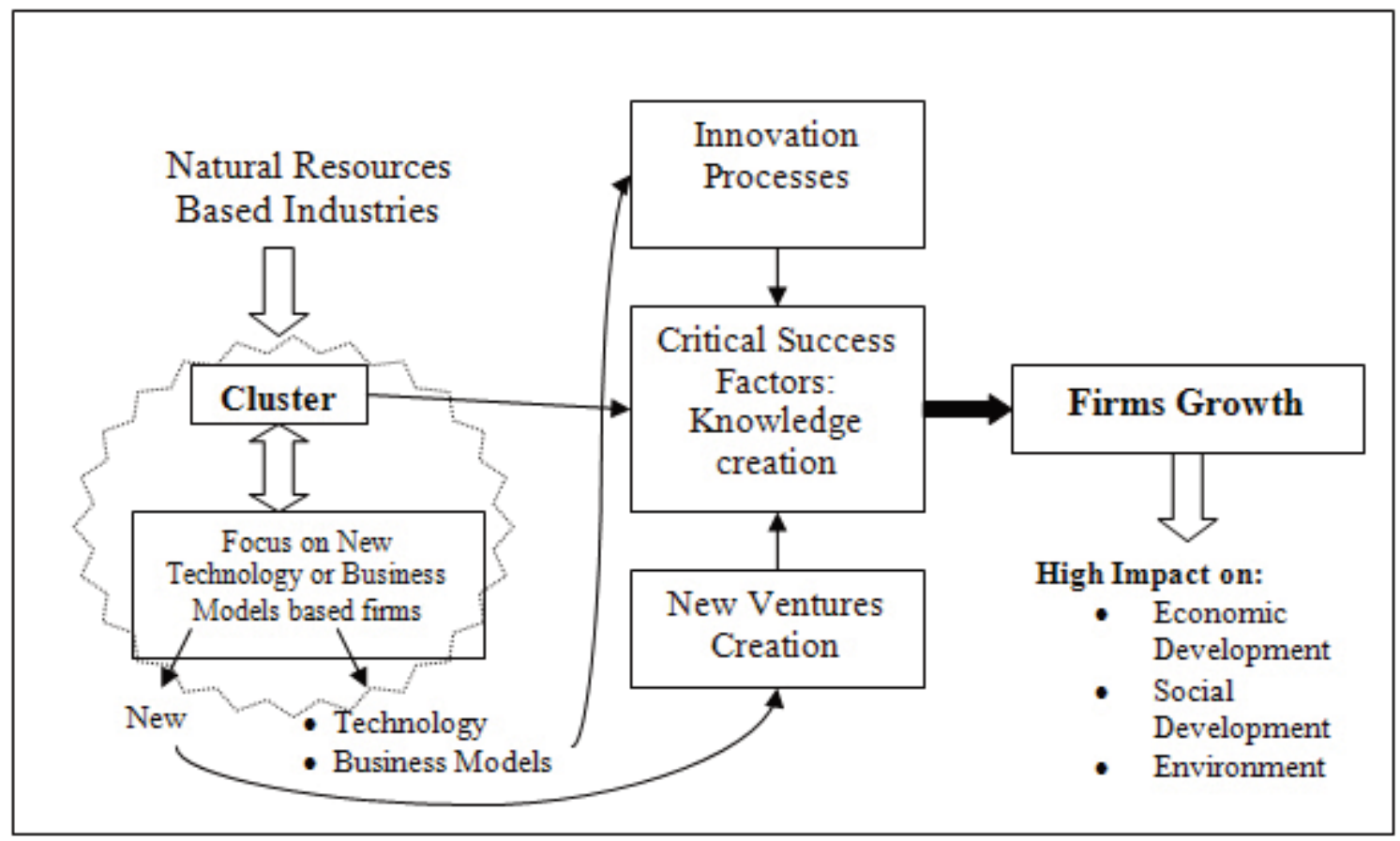

Figure 5: Proposal of Research Model

\section{References}

Acs, Z.; Arenius, P.; Ha, M. and Minnit, M. (2005): Global Entrepreneurship Monitor 2004 Executive Report, Babson College and London Business School. Babson Park, MA. and London, UK

Amorós, J.; Cortés, P.; Echecopar, G. and Flores, T. (2006): Global Entrepreneurship Monitor, Reporte Chile, 2005. Universidad Adolfo Ibáñez-Universidad del Desarrollo. Santiago. Chile

Audretsch, D. (1995): Innovation and Industrial Evolution. Boston: MIT Press.

ISSN: 07I8-2724. (http://www.jotmi.org)

JOURNAL OFTECHNOLOGY MANAGEMENT \& INNOVATION ( ) JOTMI Research Group
Bas,T.G. (2006): “La Gestión Tecnológica en América Latina. Un desafío Inconcluso”. Journal of Technology Management \& Innovation. Vol. I, Issue 4, pp. I-6.

Bas, T.G. and Niosi, J. (2007): “The Issue of Asymmetrical Growth in Specialized Biotechnology Firms in the United States and the United Kingdom”. International Journal of Biotechnology, vol. 9, Issue I, pp. 87-100.

Bas, T.G. and Kunc, M. (forthcoming): "National Systems of Innovations and Natural Resources Clusters: Evidence from Copper Mining Industry Patents” European Planning Studies. 
Batista,J.C. (200I): Estrategia de desarrollo de clusters basados en recursos naturales: el caso de la bauxita en el norte de Brasil. Santiago: CEPAL

Benavente, J.M. (2004): "Innovación Tecnológica en Chile. ¿Dónde estamos y Qué se Puede Hacer?” Central Bank of Chile.Working Papers No 295.

Birch, D. (1987): Job Creation in America. New York:The Free Press.

Bitran, E. (200I): “Crecimiento e Innovación en Chile”. Corporación Expansiva. www.expansiva.cl.

Block, Z. and MacMillan, I.C. ( 1993): Corporate Venturing: Creating new business within the firm, Boston: Harvard Business School Press

Bonin, B. and Desranleau, C. (1988) : Innovation industrielle et analyse économique. Gaëtan Morin éditeur. Montreal.

Burt, R. (2005): Trust, Reputation and Competitive Advantage. New York: Oxford U Press.

Casas, R..; Etzkowitiz and Carvalho de Mello, J. (2005): Knowledge for Innovation: New Directions for Latin American University-Industry-Government Interactions. New York: SUNYPress.

Constantino, R. (2004): “Los mercados de tecnología ambiental y la construcción de capacidades institucionales para la gestión ambiental: Notas para el caso mexicano", Análisis Económico, Vol. XXI (42) p. I99-24I.

Crespi, G. (2003): Pyme en Chile: Nace, crece y muere. Santiago: FUNDES.

Drucker, P. (1985): Innovation and Entrepreneurship. New York: Harper Business.

Dutrénit, G. and Katz, J. (2005):"Innovation, Growth and Development in Latin-America: Stylized Facts and a Policy Agenda. Innovation: Management, Policy \& Practice.Vol. 7. No 2.

Easterly,W. and Levine, R. (2002): “It's Not Factor Accumulation: Stylized Facts and Growth Models”. Economic Growth: Sources, Trends and Cycles. In Loayza, N. and Soto, R. (Ed.) Banco Central de Chile.

Echecopar, G. (2004): “Incubating innovative start-ups: some lessons for Chile”. In S.Tiffin (ed). Entrepreneurship in Latin Ame- rica. Westport: Preger Publishers.

Echecopar, G. and Tiffin, S. (2002): A Public Sector Mechanism for Creating Entrepreneurial Firms. Fundación Chile, Boston: Babson College, 2002.

Fagerberg, J. and Verspagen, B. (2003): "Innovation, Growth and Economic Development: Why Some Countries Succeed and Others Don't". Conference: Innovation Systems and development Strategies for the Third Millenium. Rio de Janeiro. Brazil.

Feldman, M. (200I): “The Entrepreneurial Event Revisited: Firm Formation in a Regional Context”, Industrial and Corporate Change, Vo. 10, No. 4.

Florida, R. (2002): The Rise of the Creative Class. New York: Basic Books

Freeman, C. (1987), Technology Policy and Economic Performance: Lessons from Japan, London, UK: Pinter.

Gibson, D. and Stiles, C. (2000): "Technopoleis, Technology Transfer and Globally Networked Entrepreneurship”. In, Conceicao, P. (ed.), Science, Technology and Innovation Policy. Westport: Quorum.

Gomes-Casseres, B. (1996): The Alliance Revolution:The New Shape of Business Rivalry. Cambridge: Harvard U Press.

Hall, P. (1999): Cities in Civilization. London: Phoenix.

Hojman, D. (2005): “Network Learning, Principal-Agent Conflict and Award-Winning Wine-Making in Chile's Colchagua Valley”. Research Paper Series, No 2005/I2, The University of Liverpool Management School.

Ireland, D.; Hitt, M. and Sirmon, D. (2003): “A model of strategic entrepreneurship: the construct and its dimensions”. Journal of Management, Vol. 29 (6).

Katz, J. (2000): Reformas Estructurales, Productividad y Conducta Tecnológica en América Latina, Santiago de Chile: CEPAL/Fondo de Cultura Económica.

Katz,J. (200I), "Structural Reforms and Technological Behaviour: The Sources and Nature of Technological Change in Latin America in the 1990's", Research Policy Vol. 30.

Keroack, M.; Ouimet, M. and Landry, R. (2003): “Networking and Innovation in the Quebec Optics/Photonics Cluster", in Wolfe, D. and Lucas, M. (eds.) Clusters in a Cold Climate. Montreal \& 
Kingston: Queen's-McGill U Press.

Kunc, M. (2006), “Knowledge Management in Natural Resource Based Sectors:The case of Chile" 3rd International Conference on Intellectual Capital, Knowledge Management and Organizational Learning, Santiago (Chile).

Kunc, M. (2007), "A Survey of Managerial Practices in the Chilean Wine Industry. Journal of Wine Research, I8: I I3-I 19.

Kunc , M. and Bas, T.G. (2007), “Upgrading the Chilean wine industry: Has the national system of innovations had a role in its evolution?" 3rd International Conference on Wine - Bacchus at Brock, Brock University - Canada.

Kunc, M. (2008), "A Review of the Development of Wine Tourism in Chile", 4th International Conference of the Academy of Wine Business Research, Siena, July, 2008.

Landry, R. and Amara, N. (2004) : Identification des clusters dynamiques. Ottawa: Ministère du Développement Economique et Régional.

Mayorga, R. ( 1997): Cerrando la Brecha, BID,Washington D.C., No SOC97-I0I.

Miles, R.; Miles, G. and Snow, C. (2005): Collaborative Entrepreneurship. Palo Alto: Stanford University Press.

Minniti, M.; Bygrave, W. and E. Autio. (2006): Global Entrepreneurship Monitor, Executive Report 2005. Babson Collage and London Business School. Babson Park, MA. and London, UK

Montero, C. (2004): Formación y desarrollo de un cluster globalizado: el caso de la industria del salmón en Chile. Santiago: CEPAL.

Mullin, J.; Adam, R.; Halliwell, J. and Milligan, L. (2000): Science, Technology, and Innovation in Chile. IDRC, Ottawa, Canada.

Nelson, R. ( 1993): National Systems of Innovation. Oxford University Press, UK.

Niosi, J. and Bas, T.G. (200I): "The Competencies of Regions Canada's Clusters in Biotechnology”. Small Business Economics, vol. 17 p. 3 I-42.

Niosi, J. and Bas, T.G. (2004): "Canadian Biotechnology Policy: Designing Incentives for a New Technology”. Environment and Planning C: Government and Policy, Vol. 22, o. 233-248.
Niosi, J. (2005): Canada's Regional Innovation Systems: The Science-Based Industries. Montreal \& Kingston: Queen's-McGill U Press.

Nonaka, I. and Takeuchi, H. (1995): The Knowledge-Creating Company. New York, NY: Oxford University Press.

Penrose, E. (1959):The Theory of the Growth of the Firms. M.E. Sharpe, Inc. White Plains, New York.

Perez, C. (200I): "Technological Change and Opportunities for Development as a Moving Target”. CEPAL Review, No 75, Santiago.

Porter, M. (1990):The Competitive Advantage of Nations, Free Press, New York.

Porter, M. (2000):"Clusters and the new economics of competition", Harvard Business Review, Vol. II.

Price, R. (1996) :"Quand la technologie fait la différence“, L’Expansion Management Review, pp. I254-3 176.

Roberts, E. (2002): Innovation. San Francisco: Jossy-Bass.

Romer, P. (1990):“Endogenous Technological Change”, Journal of Political Economy, Vol. 98, p. 7I-102.

Rosenberg, S. (2002): Creating Smart Systems:A guide to cluster strategies in less favoured regions. Carrboro, NC: Regional Technology Strategies Inc.

Rosenberg, N. and Birdzell, L. (1996): How the West Grew Rich: The Economic Transformation of the Industrial World. New York: Basic Books.

Sachs, J. and Warner,A. (200I): “Fundamental Sources of LongRun Growth". American Economic Review, Papers and Proceedings Vol. 87 (2): I84- I 88.

SalmonChile (www.salmonchile.cl).

Schumpeter J. (191 I; rpt 1934): The Theory of Economic Development. Cambridge, MA: Harvard University Press

Schumpeter, J. (1942): Capitalism, Socialism and Democracy, London: George Allen \& Unwin.

Science Council of Canada (197I): Innovation in a Cold Climate. Report \#15. Ottawa: Information Canada. 
SOFOFA (2004): La industria chilena en cifras, Santiago, Chile.

Solow, R. M. (1956): "A Contribution to the Theory of Economic Growth“", Quarterly Journal of Economics, 70, p. 65-94.

Stevenson, H., Roberts, M., Grousbeck H.I. and Bhidé,A. (1999), New Business Ventures and the Entrepreneur, 5th ed. Chicago: Irwin.

Tiffin, S. (2004): Entrepreneurship in Latin America. New York: Praeger Press

Tiffin, S. and Bortagaray, I. (2002): "Local Innovation Clusters in Latin America", in M. Heitor, D. Gibson and M. Ibarra, Technology Policy and Innovation, Vol. 5. (eds.) Quorum Books.

Timmons, J.A. and Spinelli S. (2003): New Venture Creation 6th ed. Boston: McGraw- Hill.

Torres-Zorrilla,J. (2000): Una estrategia de desarrollo basad en recursos naturales: análisis cluster del complejo de cobre de la Southern Peru. Santiago: CEPAL.

Visser, E-J. (2004):A Chilean Wine Cluster? The Quality and Importance of Local Governance in a Fast Growing and Internationalizing Industry. CEPAL, Santiago, Chile. 